\title{
Post-Licensure RN to BSN Nursing Students: Maintaining Collaboration and Engagement via Technology with Community-based Agencies
}

\author{
Mary Grace Amendola ${ }^{1^{*}}$ and Laura Jackson ${ }^{2}$ \\ ${ }^{1 *}$ Assistant Professor, School of Nursing, University of North Florida, United States. \\ ${ }^{2}$ Center for Instruction and Research Technology, University of North Florida, United States.
}

\begin{abstract}
Article Details
Article Type: Review Article

Received date: $06^{\text {th }}$ November 2021

Accepted date: $24^{\text {th }}$ December, 2021

Published date: $27^{\text {th }}$ December, 2021

Corresponding Author: Mary Grace Amendola, Assistant Professor, School of Nursing, University of North Florida, United States. E-mail: m.g.amendola@unf.edu

Citation: Amendola, M.G., \& Jackson, L. (2021). Post-Licensure RN to BSN Nursing Students: Maintaining Collaboration and Engagement via Technology with Community-based Agencies. J Pub Health Issue Pract 5(2): 192. doi: https://doi. org/10.33790/jphip1100192

Copyright: $\mathbb{0} 2021$, This is an open-access article distributed under the terms of the Creative Commons Attribution License 4.0, which permits unrestricted use, distribution, and reproduction in any medium, provided the original author and source are credited.
\end{abstract}

\begin{abstract}
Academic learning software is vital when conducting online post-licensure RN to BSN courses, especially when maintaining collaboration and engagement with community-based agencies. This paper will discuss Osprey Impact as an example of a possible solution to streng then collaborative partnerships between RN to BSN students and their chosen community-based agency, by streamlining the process of logging and tracking community clinical hours using this software. This online interface also tracks the progression of the RNs community/public health promotion projects with their community-based agency and faculty. The University of North Florida School of Nursing (UNF) and its Center for Instruction and Research Technology worked together to solve the problem through technology.
\end{abstract}

Keywords: RN to BSN Nursing Students, Collaboration, Engagement, Community-based Agency, OspreyImpact (software - GivePulse), School of Nursing and Center for Instruction and Research Technology

\section{Background}

The University of North Florida (UNF) Center for CommunityBased Learning (CCBL) promotes a Community Scholars Program (CSP) that supports practice for UNF faculty and student affairs professionals committing to community-based transformational learning (CBTL). Each year a cohort of faculty from different disciplines are selected to participate in the CSP. This program also awards two stipends to execute a project that uses CBTL strategies [1]. These awards provided a timely opportunity to help solve the problem of continuity in engagement and collaboration between post-licensure RN to BSN students and community-based agencies.

Community-based transformational learning (CBTL) creates and develops learning experiences for students in a community-based environment that augments students' academic study, plays a part in expanding students' worldview and personal growth, and fosters community collaborations while concomitantly helping communities where these learning activities are established $[2,3]$.

A unique aspect of our undergraduate nursing program is our commitment to CBTL. Experiential learning prepares our nursing students for successful interdisciplinary practice across a continuum of care with diverse populations, thus developing students' intercultural competence (CBTL outcome). It also prepares student nurses to be effective citizens (CBTL outcome) in their career. The first C/PHN clinical course prepares RN students to select a community-based agency with the approval of the instructor. Students then proceed to make an appointment for a two-hour orientation at their established community-based agency. The second portion of the $\mathrm{C} / \mathrm{PHN}$ clinical course involves identifying health problems in collaboration with the community-based agency. A common occurring problem is that some students do not consistently and procedurally collaborate with the agency and faculty; and as a result, independently propose their own project that may not benefit the agency and community/population being served. Each project assignment is based on a progression of collaborative steps to complete the health promotion and prevention project. If students do not initially collaborate with the faculty and agency then they are delayed in proceeding with the project.

The current collaboration process involves using hand-written logs to verify students' hours, and requires instructors to contact agencies to confirm students are meeting the expectations of collaboration and engagement with health promotion and prevention projects. This is a time-consuming and ineffective process. A more comprehensive solution is to use a Learning Management System (LMS) to track the students' collaboration, engagement, hours, and progression of their health promotion projects with their community-based agency and faculty [5].

Learning Management Systems are increasingly being relied upon in higher education institutions. Canvas is the LMS currently being used at the University of North Florida. This system is a web-based LMS that assists in managing our online course learning material and student learning assessments. Canvas has many features such as assignments, discussions, modules, and quizzes, to name a few [6]. Canvas, however, does not have a management tool or component to maintain clinical hours, including engagement and collaboration with community-based agencies, the clinical component of the $\mathrm{C} /$ PHN course. In the past, UNF used Blackboard, an academic learning system software platform, to manage students' clinical hours, engagement and collaboration with their community partners [4]. There is software program, OspreyImpact (by GivePulse) that can be used.

OspreyImpact to Track Collaboration and Engagement with Community Partners

OspreyImpact allows students to track online their courses and 
extracurricular community service hours. Students access OspreyImpact using their student identification number, which allows their clinical hours to be tracked across multiple academic courses, and also track their extracurricular activities throughout their time at UNF. Faculty and community partners can communicate with students directly through this platform rather than relying only on common communication methods (e.g. email, phone), thus improving communication. Other benefits include removing the faculty as the intermediary, enabling students to directly submit their completed clinical hour's information, and eliminating the need to submit paper timesheets. Students can also upload images and documents regarding their health promotion projects, to share with faculty and community partners as needed. After a student submits their clinical hours, documents, and images, the community partner and faculty is immediately notified via email and asked to verify the student's hours as well as their projects progress. Hours and progress with students' projects are verified (or rejected) by the community partner with a single keyboard click. All of this information is stored in the same place and reports can easily be generated to see individual students' clinical hours and health projects progression [7].

\section{Student Benefits and Barriers in Participating with Software}

The availability of this software benefits student by allowing them to track their time electronically, rather than on paper, and it can help jog students' memory regarding the work completed at the agency. Agencies have the ability to post events and other information to the site as well, which could encourage students to be more active with their chosen agency (or other agencies they may be interested in). Additionally, a dedicated OspreyImpact administrator is available to help students, faculty, and agencies, to learn this technology. Finally, OspreyImpact is also available via a free app, which students can use to report and track their hours, and provides them visual reminders regarding their responsibility for learning and accessing available resources $[7,8]$. Barriers that may hinder students in the use of this software system can be a negative personal attitude, fear or discomfort with new technology, inadequate internet access and networking, and not having available technical support when needed [9].

\section{Recommendations}

As with any new software, training is an important first step that can't be overlooked. Faculty, community partners, and students, will need specific instructions on how to utilize this tool to ensure ease of adoption and use. Programs with community-based learning components should consider using OspreyImpact software to moreeasily track student engagement throughout their program. In the spirit of continuous improvement, midterm and final semester surveys could be developed that focus on stakeholders' experiences using OspreyImpact to identify ways to improve its implementation.

\section{Conclusion}

This project's focus is to strengthen collaboration and engagement with post-licensure RN to BSN students and their community-based agency, using software technology. The UNF SON partnered with UNF's Center for Instruction and Research Technology exploring the use of OspreyImpact software by GivePulse. Thorough out this exploratory process it became apparent that replacing a "paper system" with technology could help RN students and faculty maintain, and enhance collaboration and engagement with their community partners. The implementation of this project will take place in the spring of 2022, and its findings and recommendations will be published in the fall of 2023 .

Conflict of interest: The authors have declared no conflict of interest.

\section{References}

1. University of North Florida (n.d). Community Scholars Program. Retrieved on January 18, 2021, from https://www.unf. edu/ccbl/Community_Scholars_Program.aspx
2. Gardner, J., Ronzio, C., Snelling, A. (2018). Transformational learning in undergraduate public health education: Course design for generation Z, Pedagogy In Health Promotion, 4(2),95-100.

3. University of North Florida (n.d). Community-based outreach and volunteering. Retrieved on January 18, 2021, from https://www.unf.edu/ccbl/Community-Based_Outreach_and_ Volunteering.aspx

4. Kruger, B. J., Ahrens, W. D., Miller, D., Soles, E., Connelly, L. \& Turrin, T. (2008). Blackboard unites service-learning partnerships. Academic Exchange Quarterly, 12(1), 148-152.

5. Washington-Brown, L., Ritchie, A. (2014). The fundamentals of integrating service in a post-Licensure RN to BSN Program, The ABNF Journal. 46-51.

6. CANVAS (2020). What is CANVAS? Retrieved on January 15, 2021, from https://community.canvaslms.com/t5/CanvasBasics-Guide/What-is-Canvas/ta-p/45

7. University of North Florida (n.d). OspreyImpact. Retrieved on January 19, 2021, from https://www.unf.edu/ccbl/ OspreyImpact.aspx

8. Hall, K.L., Lawver, R.G., McMurray, K., \& Hawley, J.L. (2017). Students' perceptions of using a course management system to supplement traditional advising. NACTA Journal, 61(2).97-101.

9. Alenezi, A. (2018). Barriers to participation in learning management systems in Saudi Arabian Universities, Hinduri, Education Research International, 1-8. https://doi. org/10.1155/2018/9085914 